\title{
Lauro, um operário amigo da classe dominante do Paraná nos anos 1920
}

\author{
Eliana Ferreira de Mattos ${ }^{1}$
}

RESUMO: O artigo trata da biografia do tipógrafo Lauro Ferreira de Mattos que trabalhou na Gazeta do Povo de 1927 a 1939 onde recebia e distribuía informações imprescindíveis para produtores agrícolas, políticos e empresários interessados em saber com antecedência instruções favoráveis com as quais providenciariam os devidos comandos que iriam influenciar no destino a ser dado as suas plantações, produtos e negócios. Através da análise da trajetória de Lauro, o tipógrafo, será possível perceber os desmandos e o trânsito de livre acesso as informações privilegiadas que os indivíduos da classe dominante detinham no Paraná das décadas de 1920,30 e 40.

Palavras-chave: Mídia. Política. Parentesco.

\section{Lauro, a worker friend of the ruling class of Parana in the 1920s}

\begin{abstract}
The article deals with the biography of the typographer Lauro Ferreira de Mattos, who worked in the Gazeta do Povo from 1927 to 1939 where he received and distributed essential information to agricultural producers, politicians and businessmen interested in knowing in advance favorable instructions with which they would provide the necessary commands Influence the destination to be given to their plantations, products and business. Through the analysis of the trajectory of Lauro, the typographer, it will be possible to perceive the desmandos and the traffic of free access the privileged information that the individuals of the dominant class had in the Paraná of the decades of 1920, 30 and 40.
\end{abstract}

Keywords: Media. Policy. Kinship.

- Enviado em 01/05/2017

- Aprovado em 17/05/2017

\footnotetext{
1 Licenciada em Pedagogia pela UNINTER/FACINTER (2010). Especialista em História, Arte e Cultura pela Universidade Estadual de Ponta Grossa (UEPG, 2012). Especializanda em Filosofia da Educação pela Universidade Federal do Paraná (UFPR, 2015). Especializanda em Mídias na Educação pela Universidade Federal do Paraná. Uma versão preliminar desse texto foi apresentada no VIII Seminário Nacional de Sociologia e Política realizado de 17 a 19 de maio de 2017 na UFPR. E-mail likay1@hotmail.com
} 


\section{$\underline{\text { Lauro Ferreira de Mattos }}$}

* Curitiba 03/07/1902

$\dagger$ Curitiba 26/05/1978

- Ainda rapaz envolveu- se com pintura, gravura e fotografia.

-Habilidoso era muito procurado por suas correções ortográficas.

. Gazeta do Povo: de 1927 a 1939.

- Foi chamado para "diagramar" o jornal do alagoano Oscar Joseph de Plácido e Silva e do paraibano Benjamim Lins.

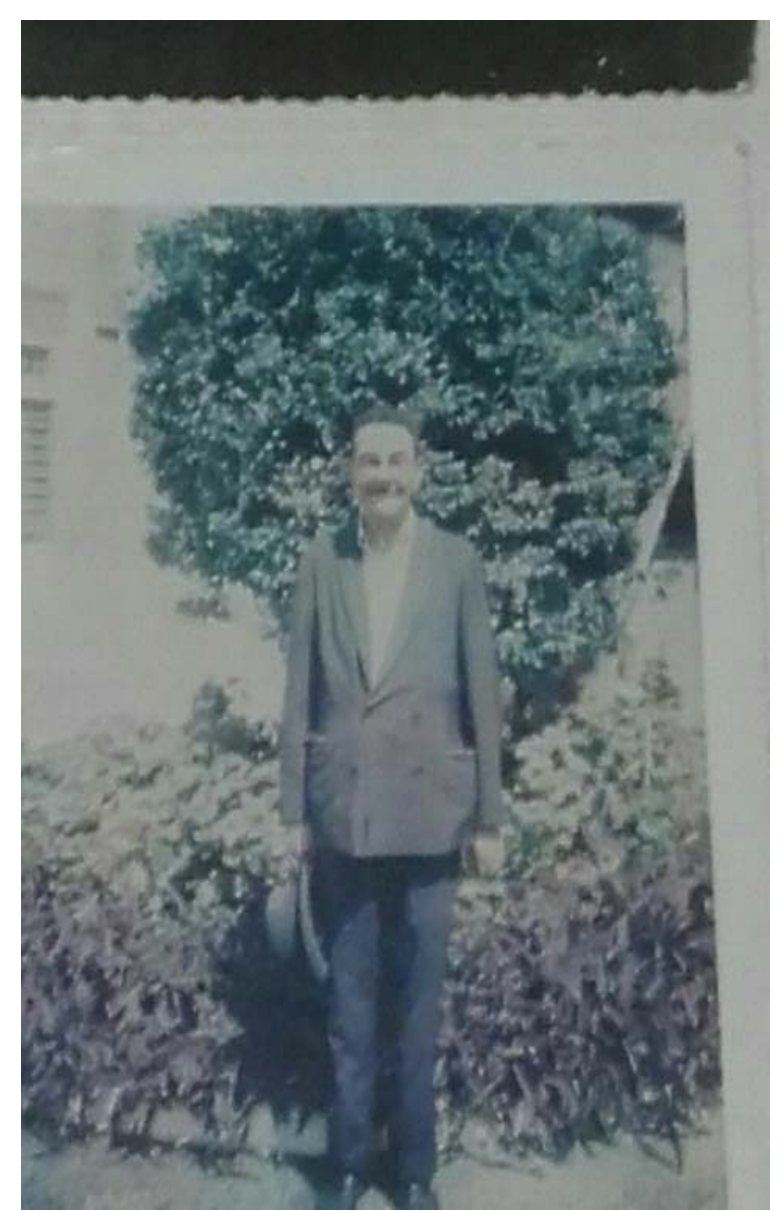

Foto de Lauro Ferreira Matos na década de 1970 Acervo da autora 
Objetivo geral: Através da biografia de Lauro Ferreira de Mattos demonstrar a relação entre a classe dominante e a classe trabalhadora (Lauro, o tipógrafo da Gazeta do Povo, articulador na formação de uma rede de venda de informações privilegiadas)

\section{- Objetivos específicos:}

- Realizar o levantamento das principais personalidades dos grupos sociais envolvidos na aquisição das informações: os que tinham interesse em comprar terras a baixo custo com a crise do café e os que desejavam manter estreitas relações com a elite do interior que muitas vezes amparava financeiramente seus familiares aqui na capital em disputas políticas.

- Analisar os gestores municipais da capital Curitiba e da cidade de Jacarezinho no Norte Velho do Estado do Paraná do período estudado.

- Descrever o papel da mídia quanto à manipulação, o adiantamento e o sigilo de informações.

\section{- Metodologia:}

Norbert Elias: Configuração de rede. Biografia.

Pierre Bourdieu: Agentes Sociais. Habitus. Campo. Mercado. Poder Simbólico. Espaço Social .

Peter Burke: Memória. História Oral. Identidade.

Ricardo Costa Oliveira: Genealogia. Classe Dominante. Instituições Políticas.

Erving Goffman: Estigma. Identidade Deteriorada. Manicômio.

\section{-Pesquisa (levantamento de dados):}

Arquivos do Jornal Gazeta do Povo.

Arquivos do Asilo São Vicente de Paula.

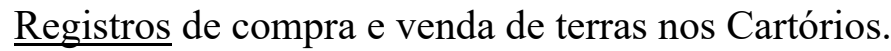

Questionários abertos e fechados.

Entrevistas e relatos orais.

Pesquisa eleitoral. 


\section{- Considerações Finais:}

- Aprofundar os estudos sobre política, famílias tradicionais, mídia e classe dominante no Paraná.

- Entender que as relações entre mídia e política são muito complexas, e verificar quem são as pessoas que ocuparam posições formais nos setores políticos - administrativos, que configuraram essa rede de poder, fator imprescindível para sabermos quem ganhou e quem perdeu com a crise do ouro verde paranaense.

- Avaliar como era o cenário político paranaense e brasileiro no período, ou seja como era a classe dominante na época em que Lauro, o tipógrafo, distribuiu essas informações.

- Levantar como Lauro construiu esse esquema de negociação de informações privilegiadas sobre vendas de terras no norte do Paraná.

\section{Referências:}

BOURDIEU, Pierre. O poder simbólico. Rio de Janeiro: Bertrand Brasil.1977.

BURKE, Peter. O que é História Cultural? Rio de Janeiro: J. Zahar, 2005.

ELIAS, Norbert \& SCOTSON, John L. Os Estabelecidos e os Outsiders: Sociologia da Relações de Poder a partir de uma pequena comunidade. Rio de Janeiro: Jorge Zahar, 2000.

GOFFMAN, Erving. Manicômios, Prisões e Conventos. Tradução de Dante Moreira. Leite. $7^{\mathrm{a}}$ edição. São Paulo: Editora Perspectiva, 2001.

MARX, Karl. O Capital: crítica da economia política. Livro I. Volume 1. Tradução de Reginaldo Sant'Anna. 2a ed. Rio de Janeiro: Civilização Brasileira, 2005.

OLIVEIRA. Ricardo Costa de. O silencio dos vencedores. Genealogia, classe dominante e Estado do Paraná. Curitiba: Moinho do Verbo, 2001. 